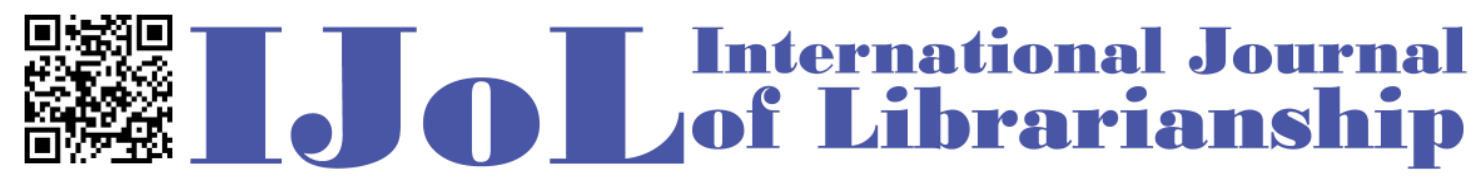

ISSN: 2474-3542 Journal homepage: http://journal.calaijol.org

\title{
A Directory to International LIS Educational Accreditation Processes: Part I
}

Xiaoai Ren

To cite this article:

Ren, X. (2016). A directory to international LIS educational accreditation processes: part I. International Journal of Librarianship, 1(1), 74-77.

https://doi.org/10.23974/ijol.2016.vol1.1.19

To submit your article to this journal:

Go to http://ojs.calaijol.org/index.php/ijol/about/submissions 


\title{
A Directory to International LIS Educational Accreditation Processes: Part I
}

\author{
Xiaoai Ren \\ The Department of Library and Information Studies, Dewar College of Education \\ and Human Services, Valdosta State University, Valdosta, Georgia, USA
}

As academic certification is the major path to enter the Library and Information Services (LIS) professions in many countries around the world, the topic of LIS educational program accreditation also is a related subject of interest within the LIS professions. Two major purposes of the accreditation activities are to ensure the high standard of LIS educational programs and to ensure the high quality of LIS graduates entering the professions. Currently, there is no international standard on accrediting LIS educational programs. With the increasing trend of globalization, there is a need for the LIS professions to understand the LIS educational accreditation processes across the world.

Dalton and Levinson (2000) identified three distinct LIS accreditation models of practice across the world:

- Professional accreditation processes where the accreditation is conducted by professional associations

- Government monitored processes where the quality control is conducted by relevant government agencies

- Internal quality audits where the LIS departments operate their own quality control measures

The IJoL dedicates this column to a review of the LIS education accreditation processes around the world. In this first issue, we introduce LIS educational program accreditation as conducted in three English-speaking countries: the United States, the United Kingdom, and Australia. These countries follow the model of professional accreditation processes. The American Library Association (ALA), the UK Chartered Institute of Library and Information Professionals (CILIP), and the Australian Library and Information Association (ALIA) have reciprocal recognition agreements with each other.

\section{United States/Canada/Puerto Rico (www.ala.org)}

\section{Accreditation Office (http://www.ala.org/offices/accreditation)}

The American Library Association (ALA) accredits master's programs in library and information studies across the United States, Canada, and Puerto Rico. ALA does not accredit doctoral, undergraduate or vocational programs. ALA accredits 63 programs at 58 institutions in the United States, Canada, and Puerto Rico. The Office of Accreditation (OA) serves as the secretariat of all operational matters associated with accreditation. The Committee on Accreditation 
(COA) is a standing committee of the ALA. It consists of 12 members. Ten members are personal members of ALA who are appointed to represent educators and practitioners. One of these members is Canadian. Two members of the COA must be appointed from the public at large to represent the public interest. The COA uses Robert's Rules of Order to govern its work. It is responsible for the execution of the accreditation program of the ALA, and for developing and formulating standards of education for library and information studies for the approval of the ALA Council. ALA accreditation is usually granted for a period of seven years.

\section{Standards for Accreditation of Master's Programs in Library and Information Studies}

(http://www.ala.org/accreditedprograms/sites/ala.org.accreditedprograms/files/content/st andards/Standards 2015 adopted 02-02-15.pdf)

The Standards are developed by the COA and approved by the ALA Council. There are five standards that cover systematic planning, curriculum, faculty, students, and administration, finances and resources. COA reviews accredited programs periodically to evaluate their compliance with the Standards.

\section{ALA Accreditation Process and Procedures (http://www.ala.org/accreditedprograms/standards/AP3)}

ALA Accreditation is a voluntary, nongovernmental, and collegial process of self-review and external verification by peer reviewers. The review process includes the submission of a Self-Study from the program, a two-day on-site review by an External Review Panel (ERP) of practitioners and academics that verifies that the program meets the Standards, and a final accreditation decision from COA.

The Self-Study document describes the program; how it meets the ALA Standards for Accreditation; analyzes its strengths, weaknesses, and challenges; and sets forth the program's plans and goals for future development and continued compliance with the Standards.

ERP visits the school and institution to validate and augment the information contained in the SelfStudy. Most visits are conducted as on-site visits in which members of the ERP travel to the program location. COA receives the recommendation from the ERP and uses these as a basis for further deliberation.

\section{The United Kingdom (www.cilip.org.uk)}

\section{Accreditation Office}

The Chartered Institute of Library and Information Professionals (CILIP) accredits Diploma, National Vocational Qualification (NVQ), undergraduate, postgraduate, master, and doctoral LIS programs. CILIP also accredits standalone modules offered to practitioners as continuing professional development activities. The aim is to provide graduates with a recognized professional qualification, based on core areas of knowledge and skills. CILIP accreditation is usually granted for a period of five years. The accreditation is managed by the Accreditation Board. The Accreditation Board reports to the CILIP Council. On CILIP website (http://www.cilip.org.uk/cilip/cilip-accredited-qualifications), there are 20 accredited programs listed.

It should also be noted that the UK provides an example of a country where a formal process of professional accreditation operates alongside a form of government monitoring. In addition to the 
formal CILIP professional accreditation process, the Quality Assurance Agency for Higher Education (QAA) has produced benchmark standards for librarianship and information management, which provides a means of government monitoring of LIS courses.

\section{Professional Knowledge and Skills Base (http://www.cilip.org.uk/jobs-careers/professional-knowledge-skills-base)}

Those who wish to apply for CILIP accreditation of their LIS programs and/or modules must demonstrate that their LIS programs and/or modules are relevant to the Professional Knowledge and Skills Base (PKSB) and provide relevant evidence. PKSB identifies the core knowledge and skills of the LIS profession. It brings the areas of professional and technical expertise together with the generic skills and capabilities required by those in the library, information and knowledge management community. All academic and vocational programs relating to library, information and knowledge management will have to demonstrate their relationship to the PKSB in order to be accredited.

In addition to course content, attention is also given to the focus of the LIS department, and the expertise, experience and professional engagement of its staff members, and the institutional support the department received such as the allocation of human and physical resources.

\section{CILIP Accreditation Process and Procedures} (http://www.cilip.org.uk/products-services/accreditation-learning-providers)

CILIP contracts with consultants to undertake assessments using the assessment criteria. There are five assessment criteria, all of which must be met. They are: the relevance of the program to the PKSB; the quality of the students' learning experience; the learning providers' connection with employers; whether the professional practice is up to date; and whether the students are encouraged to engage with CILIP. The applicant submits CILIP accreditation application and appropriate documentation in advance, followed by the initial review and assessment by the assessor. The department then receives the details of the areas the assessor wishes to explore in more depth during the visit and will confirm the final visit agenda. The assessor will visit the applicant and the accreditation assessment decision will be made. CILIP anticipates that the typical time taken from the submission being made available to the assessor and the confirmation of the outcome will normally be around 8 weeks.

All successful programs and modules are accredited for five years. Each year, CILIP staff visit every learning provider which offers an accredited program.

\section{Australia (www.alia.org.au)}

\section{Accreditation Office}

The Australian Library and Information Association (ALIA) accredits diploma, bachelor, graduate diploma and masters education programs in library and information science in Australia. ALIA accreditation is usually granted for a period of no greater than five years. In 2015, there were 24 institutions delivering 33 ALIA accredited courses around Australia. There are different ALIA accredited courses for people interested in becoming library technicians, teacher librarians or library and information professionals.

- Librarians and information specialists (undergraduate and postgraduate university courses) 
- Teacher librarians (postgraduate university courses; prospective students must be teacher-qualified to be eligible to enroll)

- Library technicians (diploma courses)

The Library and Information Sector: Core Knowledge, Skills and Attributes (https://www.alia.org.au/sites/default/files/The\%20Library\%20and\%20Information\%20Se ctor\%20Core\%20Knowledge\%20Skills\%20and\%20Attributes\%20December2014\%20\% 282\%29.pdf)

ALIA Accredited programs are measured against "the Library and Information Sector: Core Knowledge, Skills and Attributes" which are needed for effective professional practice in the Library and Information sector.

ALIA Accreditation Process and Procedures (https://www.alia.org.au/sites/default/files/documents/Education/Website\%20SUMMARY \%200F\%20ALIA\%20COURSE\%20ACCREDITATION\%20REVIEW\%20\%20November \%202015\%20update.pdf)

ALIA has two accreditation processes: Red and Gold. The Red level includes a standard accreditation process that does not include a panel visit but does allow for one person to visit the institution on a fact-finding mission on behalf of a smaller virtual accreditation panel. Gold level accreditation is an available option for any institution with a preference for a Reaccreditation Panel visit. The option for Gold accreditation is only available for institutions after successfully completing their first accreditation five-year process. Both the Red and Gold accreditation processes are measured against "The Library and Information Sector: Core Knowledge, Skills and Attributes." The individual accredited courses are monitored through the submission of an Annual Course Return (ACR) and program leaders are required to attend an ALIA-hosted education forum every year.

\section{References}

Dalton, P. \& Levinson, K. (2001). An investigation of LIS qualifications throughout the world. IFLA SET Bulletin, 2(1), 12-24. Retrieved November 15, 2016, from http://www.ifla.org/files/assets/set/Bulletin/set-bulletin-jan2001.pdf

\section{About the author}

Xiaoai Ren is an Assistant Professor in the Master of Library and Information Science program at Valdosta State University. Dr. Ren teaches courses in reference and electronic resources. She holds an M.S. in Information Management from Peking University and a Ph.D. in Information Science from the State University of New York at Albany. Her research interests include library cooperation at regional, national, and international levels, reference services, international librarianship, and eBooks in libraries. 